\title{
STUDI PERILAKU LINK PENDEK, LINK MENENGAH DAN LINK PANJANG PADA STRUKTUR BAJA SISTEM EBF
}

\author{
Jusuf Wilson Meynerd Rafael ${ }^{a}$ dan Budi Suswanto ${ }^{b}$
}

\begin{abstract}
The paper disccuses an analysis study on the design of Eccentrically Braced Frame (EBF) i.e. short link, intermediate link and long link) with K-Braces-type Split 1 floor. The analysis is performed by using ABAQUS with static monotonic loading in a single structure (frame). Each element of the frame is modeled as sholid $3 D$ with connections to every element in the form of tie constraints and given fixed on each base of the column as a boundary condition. All three models of the frame has been analyzed in accordance with the AISC 2010 provisions and then compared the behavior of each of these models. The results indicate that the short link model considered in this study have on a higher over strength value and used as a proposed model when compared to intermediate link and long link model. It is stated by the failure mechanism as well, the failure is well-occurred in the short link condition than the other models.
\end{abstract}

Keywords: short link, intermediate link, long link, steel structure, EBF

\begin{abstract}
Abstrak: Makalah ini menyajikan hasil studi numerik terhadap perilaku link pendek, link menengah dan link panjang pada sistem struktur Eccentrically Braced Frame (EBF) dengan tipe Split K-Braces 1 lantai. Penelitian ini bertujuan meneliti perilaku link pendek, link menengah dan link panjang dibawah pembebanan statik monotonik dalam satu kesatuan struktur (portal). Analisis dilakukan dengan pendekatan finite element dengan menggunakan perangkat lunak ABAQUS. Setiap elemen portal dimodelkan sebagai sholid $3 D$ dengan hubungan setiap elemennya berupa tie constraints dan diberikan perletakan jepit pada setiap dasar kolom sebagai boundary condition. Ke tiga model portal telah dianalisa sesuai dengan ketentuan AISC 2010 dan kemudian dibandingkan bagaimana perilaku setiap model tersebut. Hasil analisis menunjukkan bahwa model portal EBF tipe Split K-Braces yang menggunakan link pendek lebih baik dan dianjurkan dalam penggunaannya pada struktur dibandingkan link menengah maupun link panjang. Hal ini ditunjukkan dengan mekanisme keruntuhan pada link lebih dulu tercapai pada link pendek dibandingkan model yang lainnya.
\end{abstract}

Kata Kunci: link pendek, link menengah, link panjang, struktur baja, EBF

\section{PENDAHULUAN}

Sistem struktur Eccentrically Braced Frame (EBF) merupakan sistem yang membatasi perilaku inelastik hanya terjadi pada balok link yang berada diantara dua pengekang eksentrik, sedangkan bagian balok luar, kolom dan pengekang diagonal tetap elastik selama beban seismik bekerja. Oleh karena itu, sistem Eccentrically Braced Frame (EBF) dapat memenuhi tingkat daktilitas yang tinggi seperti Moment Resisting Frame (MRF), dan juga dapat memberikan tingkat kekakuan elastis yang tinggi seperti Concentrically Braced Frame (CBF) [1]. Beberapa kemungkinan penempatan bracing untuk sistem struktur EBF ditunjukkan dalam Gambar 1 [2].

Link dalam EBF dibentuk dari offset pada sambungan braces pada balok atau braces yang berbatasan dengan kolom sehingga selama beban seismik bekerja link menjadi aktif dan mengalami pelelehan [3]. Atau dengan kata lain link berfungsi sebagai sekering daktail (ductile fuse) selama pembebanan gempa sehingga link akan mengalami rotasi inelastik sedangkan komponen lainnya dari EBF tetap elastik [4]. Link berperilaku sebagai balok pendek dengan gaya geser yang bekerja berlawanan arah pada kedua ujungnya sehingga momen yang dihasilkan

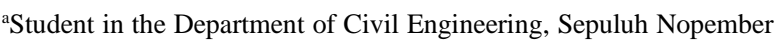
Institute of Technology (ITS), ITS Campus, Sukolilo, Surabaya 60111, Indonesia. Email: jwilson.rafael@gmail.com

${ }^{b}$ Lecturer in the Department of Civil Engineering, Sepuluh Nopember Institute of Technology (ITS), ITS Campus, Sukolilo, Surabaya 60111, Indonesia. Email: budi_suswanto@ce.its.ac.id

Note. The manuscript for this paper was submitted for review and possible publication on January 01, 2017. This paper is part of the ITS Journal of Civil Engineering, Vol. 32, No. 1, May 2017. @ ITS Journal of Civil Engineering, ISSN 2579-9029/2017.
}

pada kedua ujung balok mempunyai besar dan arah yang sama. Dalam Gambar 2 memperlihatkan gaya yang bekerja pada link di mana deformasi yang dihasilkan berbentuk $\mathrm{S}$ dengan titik balik pada tengah bentang. Momen yang dihasilkan pada kedua ujung balok adalah sebesar 0,5 kali dari besar gaya geser dikalikan dengan panjang link.

Terdapat tiga kriteria balok link yang dimungkinkan dalam sistem struktur EBF yaitu; link pendek, link menengah dan link panjang [5]. Kriteria ini ditentukan dari normalisasi panjang link dengan rasio antara kapasitas momen plastis (Mp) dan kapasitas geser plastis (Vp). Klasifikasi link ini ditampilkan dalam Gambar 3 [6] yaitu link dengan rasio panjang kurang dari 1,6 dikategorikan sebagai link pendek atau link geser dikarenakan pelelehan geser yang dominan terjadi. Link dengan rasio panjang lebih dari 2,6 dikategorikan sebagai link panjang atau link lentur disebabkan lebih dominannya pelelehan lentur. Sedangkan link dengan rasio panjang di antara 1,6 sampai 2,6 dikategorikan sebagai link menengah atau link geser-lentur dikarenakan pelelehan yang terjadi merupakan kombinasi dari geser dan lentur [5].

Penelitian yang dilakuan oleh Musmar [7] menunjukkan bahwa sistem EBF dengan pelelehan geser (shear link) lebih stabil dan menunjukkan daktilitas yang lebih dibandingkan link yang mengalami pelelehan lentur. Hal ini disebabkan gaya geser internal yang terjadi konstan sepanjang link dan pelelehan pada bagian web berlangsung sepanjang bidang web dari link. Analisa numerik yang dilakukan oleh Hashemi [8] terhadap rangka EBF dengan kriteria link panjang menunjukkan bahwa pelelehan pada balok link disebabkan karena gaya lentur. Penyerapan energi pada bagian sayap penampang 
lebih sedikit dibandingkan dengan kondisi link geser dikarenakan terjadinya premature buckling pada bagian sayap dari balok link. Untuk mengurangi hal ini maka dapat dikontrol penempatan pengaku badan pada balok link walaupun tidak terlalu efisien karena adanya pengaruh torsi.

Pemakaian link panjang lebih disukai dalam arsitektur karena lebih memungkinkan pemanfaatan area dibawah balok link untuk area bukaan [9], sedangkan link pendek selalu dianjurkan dalam pemakaian karena menunjukkan daktilitas, kekakuan dan kekuatan yang lebih baik dibandingkan tipe link yang lainnya [1]. Oleh karena itu banyak penelitian eksperimental dan analisis terdahulu yang difokuskan untuk mempelajari perilaku seismik dari link pendek.

Karena alasan inilah maka dalam studi ini akan di analisis ketiga tipe balok link tersebut yang diterapkan pada model portal EBF tipe Split K-Braces untuk mengetahui perilaku setiap tipe balok link tersebut. Selain itu, peran elemen struktur yang lain seperti balok luar,

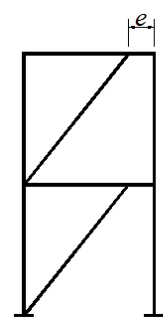

D-Braces

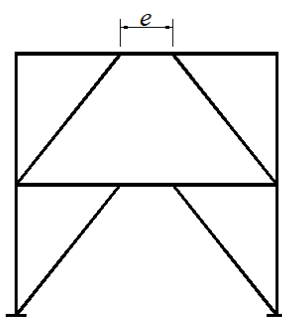

Split K-Braces

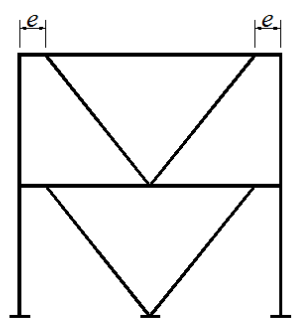

V-Braces

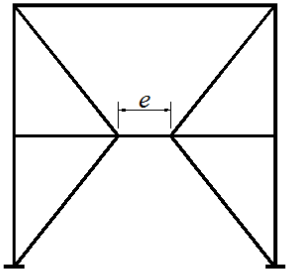

Split K \& Inverted Split K-Braces

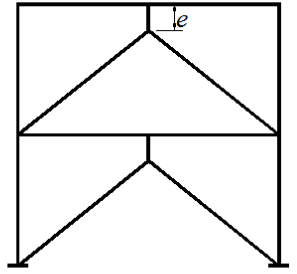

Inverted Y-Braces

Gambar 1. Beberapa Kemungkinan Penempatan Bracing untuk Sistem Struktur EBF

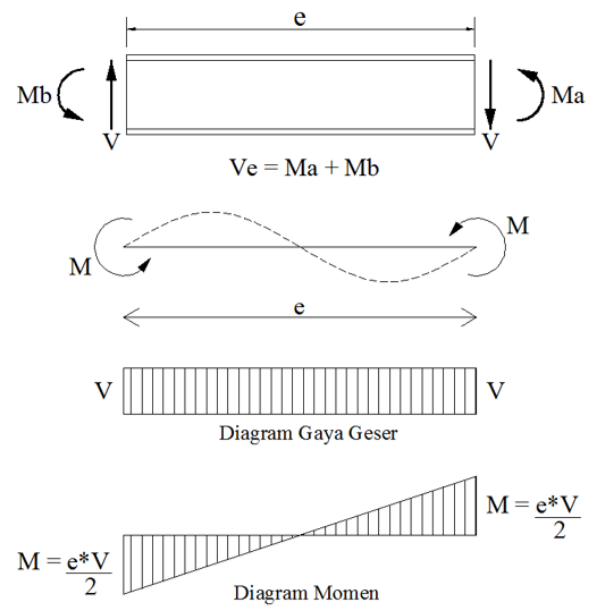

Gambar 2. Gaya yang Bekerja pada Balok Link

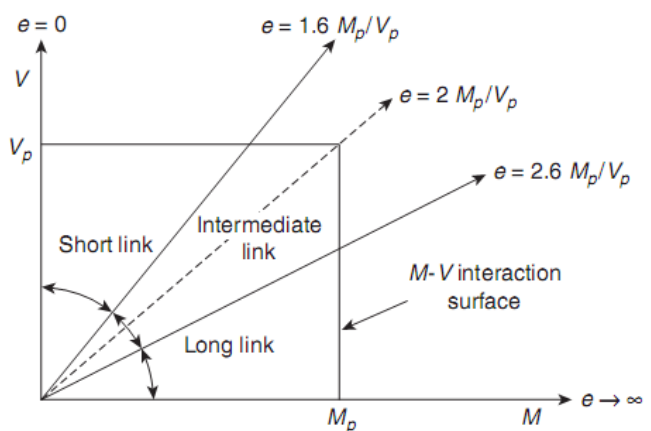

Gambar 3. Klasifikasi Link 
kolom dan braces juga mempengaruhi kinerja dari link secara keseluruhan. Sehingga selain meninjau tiga kriteria balok link, penelitian ini juga akan melihat pengaruh variasi panjang link tersebut dalam satu frame sehingga perilaku dari sistem struktur EBF dapat diperoleh secara lengkap.

\section{KEPENTINGAN RISET}

Pengujian eksperimental dan numerik yang telah dilakukan para peneliti terdahulu menunjukkan bahwa link yang mengalami pelelehan geser (link pendek) memberikan daktilitas dan kestabilan yang besar dalam menahan beban gempa. Namun, kemungkinan pemberian area bukaan dalam arsitektur menjadikan pemilihan link yang pendek terkadang menjadi tidak cukup. Akibatnya, penelitian terhadap panjang link dikembangkan yaitu link yang mengalami pelelehan lentur. Penelitian ini menjadi masukkan dalam penentuan panjang link pada perencanaan sistem struktur EBF.

\section{METODOLOGI}

Pada penelitian ini dilakukan analisis numerik terhadap portal EBF yang dibagi dalam tiga model portal yaitu EBF-1, EBF-2 dan EBF-3. Masing-masing portal mewakili kategori link pendek, link menengah dan link panjang. Profil elemen struktur portal EBF yang digunakan yaitu profil baja untuk kolom digunakan profil King-Cross (KC) 800x300x14x26, balok link dan balok

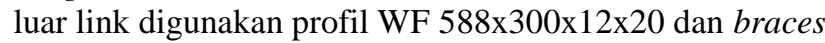
digunakan profil WF $300 \times 300 \times 15 \times 15$ (Tabel 1 dan Gambar 4). Setiap portal EBF memiliki lebar 8 meter dan tinggi portal 4 meter dengan panjang link yang digunakan ditentukan dari kapasitas momen plastis dan kapasitas geser plastis sebagai berikut:

$$
\begin{aligned}
& M_{p}=Z_{x} f_{y} \\
& V_{p}=0.6 f_{y}\left(d-2 t_{f}\right) t_{w}
\end{aligned}
$$

Dari data profil balok link yang digunakan dan perhitungan dengan persamaan (1) dan (2), didapatkan nilai $\mathrm{M}_{\mathrm{p}}=10772250 \mathrm{~kg} \cdot \mathrm{cm}$ dan $\mathrm{V}_{\mathrm{p}}=98640 \mathrm{~kg}$. Selanjutnya dari nilai $\mathrm{Mp}$ dan $\mathrm{Vp}$ yang telah diperoleh kemudian ditentukan panjang link yang dikategorikan dalam link pendek, link menengah dan link panjang dengan menggunakan persamaan berikut:

$$
\begin{aligned}
& e=1.6 \times \frac{M_{p}}{V_{p}} \\
& e=2.6 \times \frac{M_{p}}{V_{p}}
\end{aligned}
$$

Panjang link (e) yang diperoleh dari persamaan (3) dan (4) adalah sebesar $174.73 \mathrm{~cm}$ dan $283.94 \mathrm{~cm}$ yang merupakan batasan klasifikasi panjang link yaitu panjang link dibawah $174.73 \mathrm{~cm}$ dikategorikan dalam link pendek, diatas $283.94 \mathrm{~cm}$ dikategorikan dalam link panjang dan diantara kedua rentang nilai tersebut dikategorikan sebagai link menengah. Dengan demikian dipilih panjang link $100 \mathrm{~cm}$ untuk mewakili link pendek, panjang link $200 \mathrm{~cm}$ untuk mewakili link menengah dan panjang link $300 \mathrm{~cm}$ untuk mewakili link panjang seperi yang ditampilkan dalam Gambar 5. Pemberian pengaku badan pada link diperlukan untuk mencegah local buckling yang dalam Tabel 2 diberikan klasifikasi jarak pengaku badan berdasarkan AISC [10].

Tabel 1. Profil Elemen Struktural Portal EBF

\begin{tabular}{cccc}
\hline $\begin{array}{c}\text { Kolom } \\
(\mathrm{KC})\end{array}$ & $\begin{array}{c}\text { Balok Luar Link } \\
(\mathrm{WF})\end{array}$ & $\begin{array}{c}\text { Balok Link } \\
(\mathrm{WF})\end{array}$ & $\begin{array}{c}\text { Bracing } \\
(\mathrm{WF})\end{array}$ \\
\hline $800 \times 300 \times 14 \times 26$ & $588 \times 300 \times 12 \times 20$ & $588 \times 300 \times 12 \times 20$ & $300 \times 300 \times 15 \times 15$ \\
\hline
\end{tabular}

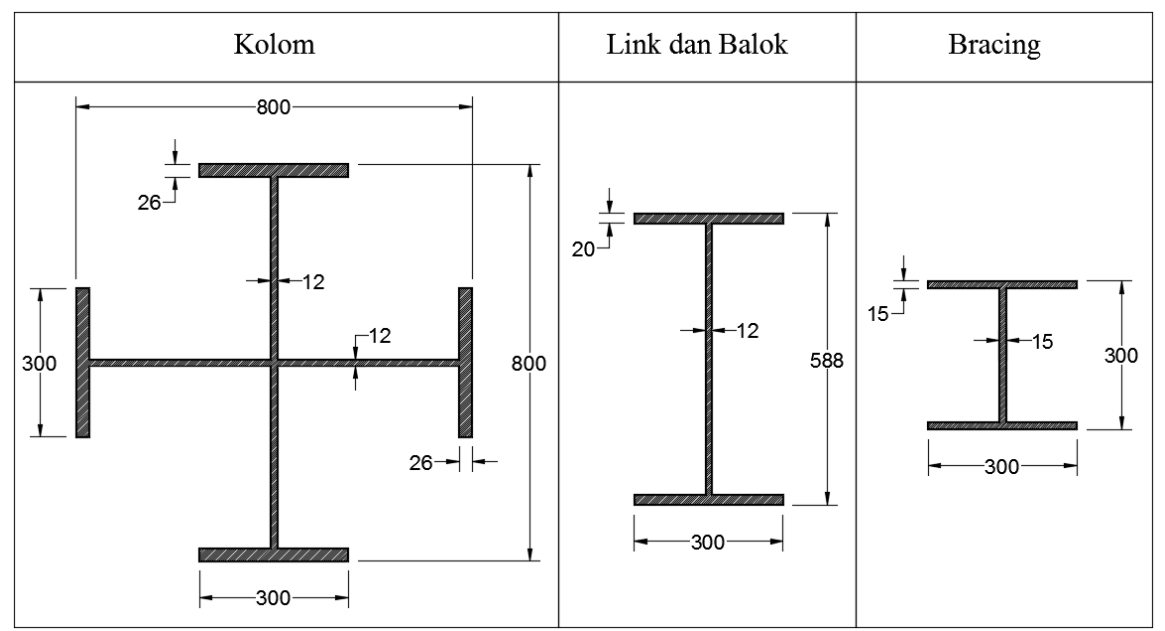

Gambar 4. Penampang Elemen Struktur EBF 


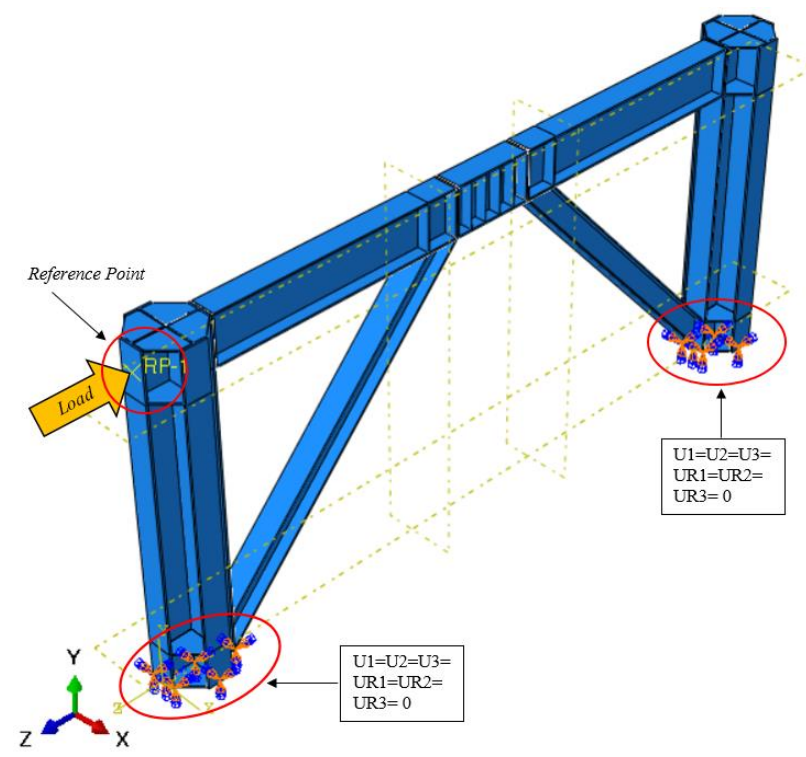

Gambar 6. Boundary Condition pada dasar kolom dan Reference Point pada puncak portal

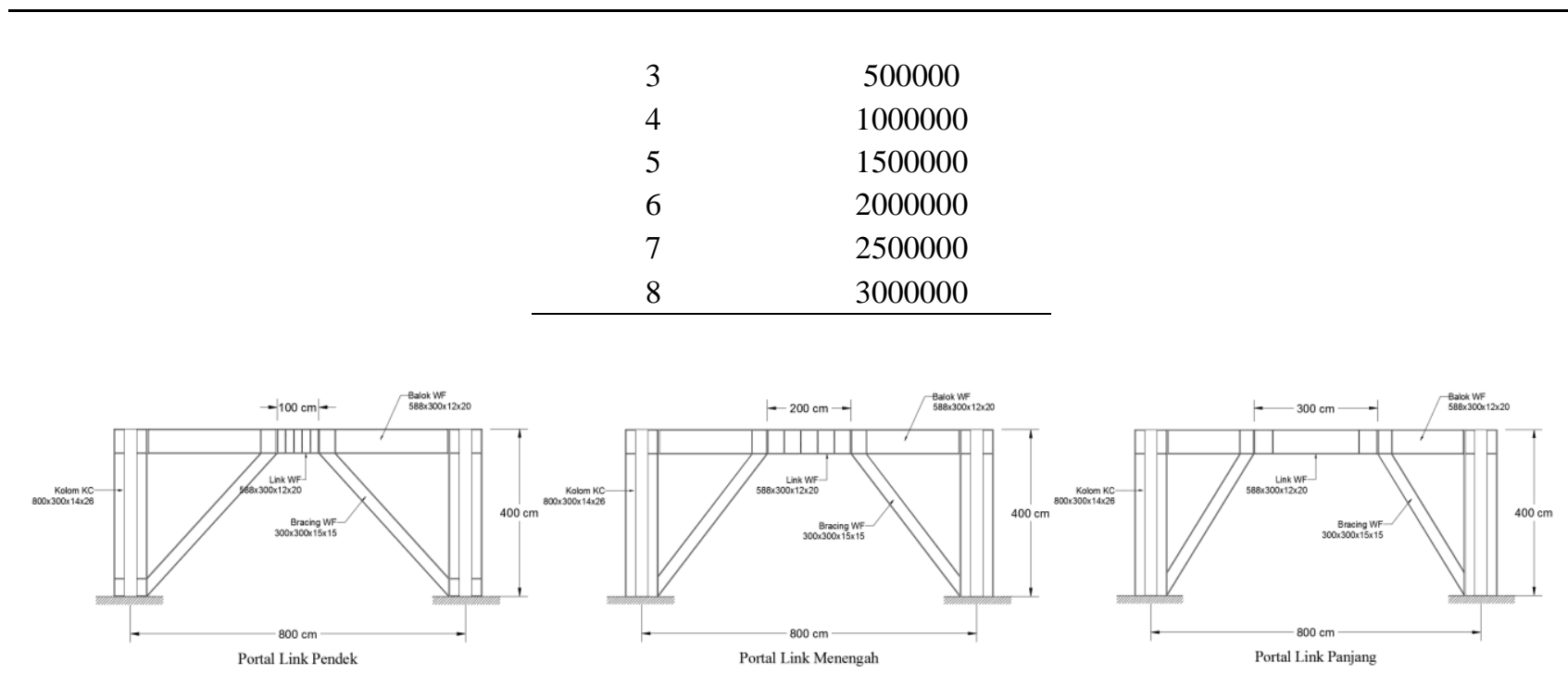

Gambar 5. Model Portal EBF

Selanjutnya dilakukan pemodelan dengan menggunakan program bantu ABAQUS versi 6.14 terhadap ketiga model portal EBF. Elemen link, balok, kolom dan braces dimodelkan sebagai elemen Sholid 3D sesuai dimensi penampang pada Tabel 1 dan Gambar 4. Data material baja yang digunakan yaitu baja BJ41 $\left(\mathrm{f}_{\mathrm{y}}=\right.$ $\left.250 \mathrm{MPa}, \mathrm{f}_{\mathrm{u}}=410 \mathrm{Mpa}\right)$ dan modulus elastisitas $\mathrm{E}=$ 200000 Mpa. Fungsi material yang digunakan dalam analisis sama untuk setiap elemen link, balok, kolom dan braces maupun pengaku badan. Adapun ketebalan pengaku badan adalah $10 \mathrm{~mm}$ dan dipasang pada kedua sisi balok link. Hubungan antara elemen diberikan dalam Tie Constraints dan Boundary Condition yang diterapkan disetiap model portal yaitu berupa perletakan jepit pada dasar kolom yang ditunjukkan pada Gambar 6 . Pembebanan yang diberikan terhadap tiga model portal EBF adalah pembebanan statik monotonik. Pembebanan statik monotonik bertujuan untuk melihat respon model portal EBF dalam menahan beban statik, menentukan leleh pertama, melihat mode keruntuhan yang terjadi pada model tersebut serta distribusi tegangan yang dihasilkan. Beban statik monotonik diberikan pada puncak portal searah dengan elemen balok berupa Concentrated Force dengan input beban pada Reference Point. Beban dorong diberikan secara bertahap yaitu seperti yang diberikan dalam Tabel 3.

\section{ANALISIS DAN PEMBAHASAN}

Kinerja dari setiap model portal EBF dapat dilihat melalui kekuatan (strength), kekakuan (stiffness) dan disipasi energi (energy dissipation). Besarnya nilai kekuatan dan kekakuan dapat ditinjau dari kurva beban vs perpindahan yang diperoleh dari setiap model dengan pemberian beban statik monotonik. Sedangkan kemampuan portal EBF dalam mendisipasi energi dapat diketahui dengan pemberian beban siklik. Karena dalam penelitian ini hanya diberikan input beban statik monotonik, sehingga yang akan dibahas adalah kekuatan dan kekakuan dari setiap model portal EBF.

Analisa pada portal EBF-1 (link pendek) menunjukkan bahwa pada beban statik monotonik sebesar $1500000 \mathrm{~N}$ telah terlihat pelelehan sudah terjadi pada link seperti yang ditampilkan dalam Gambar 7(a). Bagian web dari link menunjukkan gradasi kontur tegangan yang 
cukup signifikan terutama pada bagian ujung balok link yang berbatasan dengan balok luar link dengan tegangan maksimum yang dihasilkan sebesar $250 \mathrm{~N} / \mathrm{mm}^{2}$. Dengan peningkatan beban menjadi $3000000 \mathrm{~N}$, seluruh bagian web dari link telah mengalami pelelehan dengan tegangan maksimum sebesar $264.87 \mathrm{~N} / \mathrm{mm}^{2}$ yang ditampilkan dalam Gambar 7(b). Pelelehan pada balok luar link juga mulai terjadi terutama pada sambungan antara balok dan link dikarenakan gaya geser yang terjadi pada link mulai menyebabkan tekuk pada bagian flange dari balok.

Untuk portal EBF-2 (link menengah) dengan pemberian beban sebesar $1500000 \mathrm{~N}$ seperti yang ditunjukkan Gambar 8(a), tegangan maksimum sebesar $250 \mathrm{~N} / \mathrm{mm}^{2}$ telah terjadi pada titik sambungan antara balok dan braces. Sedangkan pada bagian web link walaupun belum mencapai pelelehan tetapi telah menunjukkan mekanisme keruntuhan telah dimulai pada link yang terlihat dari gradasi warna kontur yang signifikan antara link dan elemen lainnya. Pada Gambar 8(b) dengan beban statik monotonik meningkat menjadi $3000000 \mathrm{~N}$, distribusi tegangan di bagian ujung dari link telah menjadi merata sepanjang bidang web dari link dengan nilai tegangan maksimum sebesar $259.78 \mathrm{~N} / \mathrm{mm}^{2}$. Pelelehan pada balok luar link juga mulai terjadi yang ditandai dengan kontur tegangan pada balok yang hampir menyerupai link.

Pada portal EBF-3 (link panjang) yang ditunjukkan Gambar 9(a) saat dikenakan beban sebesar $1500000 \mathrm{~N}$, tegangan maksimum yang dihasilkan pada link sebesar $250 \mathrm{~N} / \mathrm{mm}^{2}$ telah terjadi pada titik sambungan antara balok dan braces. Perilaku yang sama seperti yang terjadi pada portal EBF-2 yaitu distribusi tegangan lebih terpusat pada bagian sambungan antara link dan balok. Peningkatan beban statik monotonik menjadi $3000000 \mathrm{~N}$ seperti yang ditunjukkan Gambar 9(b) menyebabkan distribusi tegangan mulai meluas ke bagian tengah dari link tetapi tegangan maksimum tetap terjadi pada bagian ujung link dengan nilai sebesar $277.82 \mathrm{~N} / \mathrm{mm}^{2}$. Selain itu pelelehan akhir yang ditimbulkan telah menyebar pada sambungan balok dan link serta pada sambungan kolom dan braces.

Perbandingan antara ketiga portal EBF ditampilkan dalam Tabel 4 yaitu pengaruh peningkatan beban statik monotik terhadap tegangan dan perpindahan yang dihasilkan. Dari tabel ini kemudian dikembangkan menjadi grafik hubungan perpindahan vs beban dan perpindahan vs tegangan. Dari hasil perbandingan perpindahan terhadap beban yang ditunjukkan pada Gambar 10 menunjukkan bahwa portal EBF-1 memiliki perpindahan yang lebih kecil dibandingkan dengan portal EBF-2 dan EBF-3. Portal EBF-3 memiliki nilai perpindahan terbesar diantara ke dua portal lainnya. Perpindahan yang terjadi saat beban $3000000 \mathrm{~N}$ pada portal EBF-1 adalah sebesar $12.28 \mathrm{~mm}$, portal EBF-2 sebesar $19.25 \mathrm{~mm}$ dan portal EBF-3 sebesar $25.48 \mathrm{~mm}$. Jika portal EBF-1 dijadikan sebagai patokan

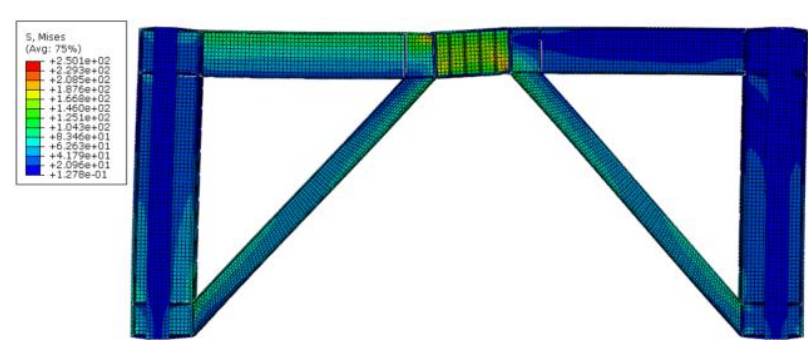

(a) Beban $1500000 \mathrm{~N}$

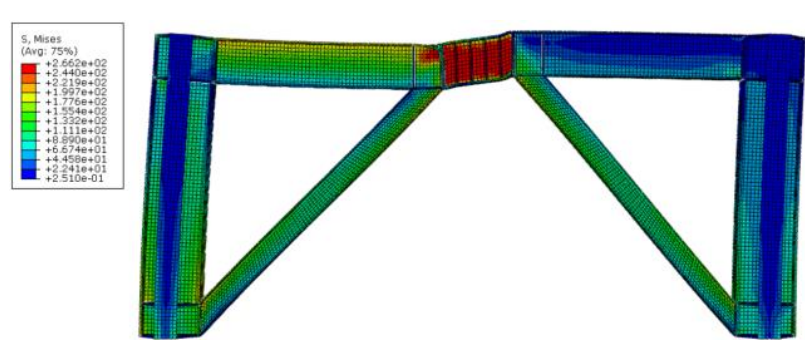

(b) Beban $300000 \mathrm{~N}$

Gambar 7. Tegangan pada Porta EBF-1

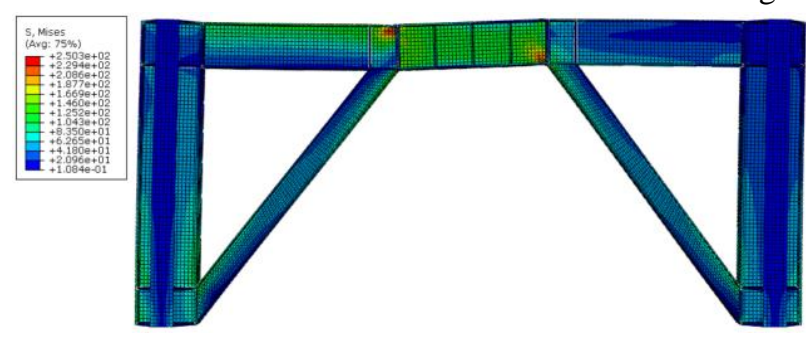

(a) Beban $1500000 \mathrm{~N}$

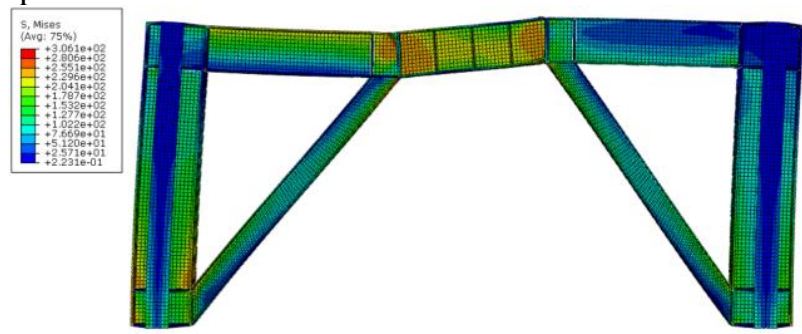

(b) Beban $300000 \mathrm{~N}$

Gambar 8. Tegangan pada Porta EBF-2

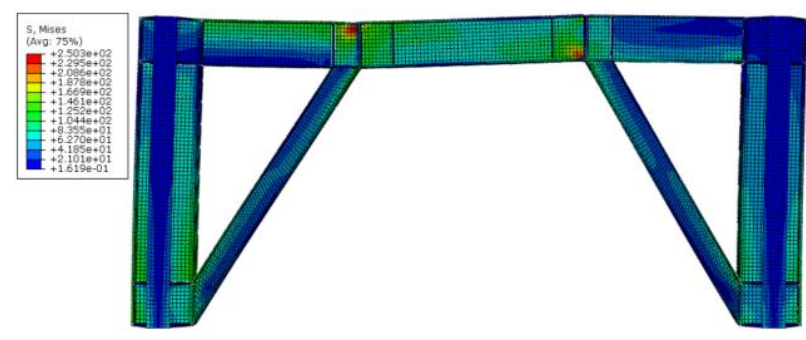

(a) Beban $1500000 \mathrm{~N}$
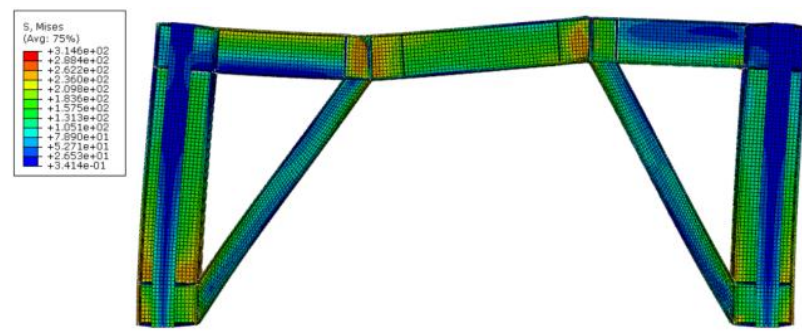

(b) Beban $300000 \mathrm{~N}$

Gambar 9. Tegangan pada Porta EBF-3 
Tabel 4. Tegangan dan perpindahan pada ke tiga portal EBF

\begin{tabular}{|c|c|c|c|c|c|c|}
\hline \multirow{2}{*}{$\begin{array}{l}\text { Load } \\
\mathrm{N} \\
\end{array}$} & \multicolumn{2}{|c|}{ EBF-1 } & \multicolumn{2}{|c|}{ EBF-2 } & \multicolumn{2}{|c|}{ EBF-3 } \\
\hline & $\begin{array}{c}\text { Stress } \\
\mathrm{N} / \mathrm{mm}^{2} \\
\end{array}$ & $\begin{array}{c}\text { Displacement } \\
\mathrm{mm}\end{array}$ & $\begin{array}{c}\text { Stress } \\
\mathrm{N} / \mathrm{mm}^{2}\end{array}$ & $\begin{array}{c}\text { Displacement } \\
\mathrm{mm}\end{array}$ & $\begin{array}{c}\text { Stress } \\
\mathrm{N} / \mathrm{mm}^{2} \\
\end{array}$ & $\begin{array}{c}\text { Displacement } \\
\mathrm{mm}\end{array}$ \\
\hline 0 & 0 & 0 & 0 & 0 & 0 & 0 \\
\hline 10,000 & 1.027 & 0.023 & 0.842 & 0.039 & 0.665 & 0.050 \\
\hline 100,000 & 10.445 & 0.237 & 8.608 & 0.400 & 6.810 & 0.522 \\
\hline 500,000 & 53.140 & 1.210 & 44.183 & 2.061 & 35.069 & 2.709 \\
\hline $1,000,000$ & 112.739 & 2.579 & 95.553 & 4.520 & 76.405 & 6.043 \\
\hline $1,500,000$ & 175.437 & 4.036 & 153.992 & 7.291 & 125.928 & 9.906 \\
\hline $2,000,000$ & 242.783 & 5.575 & 225.377 & 10.533 & 186.257 & 14.328 \\
\hline $2,500,000$ & 250.235 & 8.094 & 250.083 & 14.338 & 234.342 & 19.340 \\
\hline $3,000,000$ & 250.689 & 12.227 & 250.307 & 19.250 & 250.034 & 25.481 \\
\hline
\end{tabular}

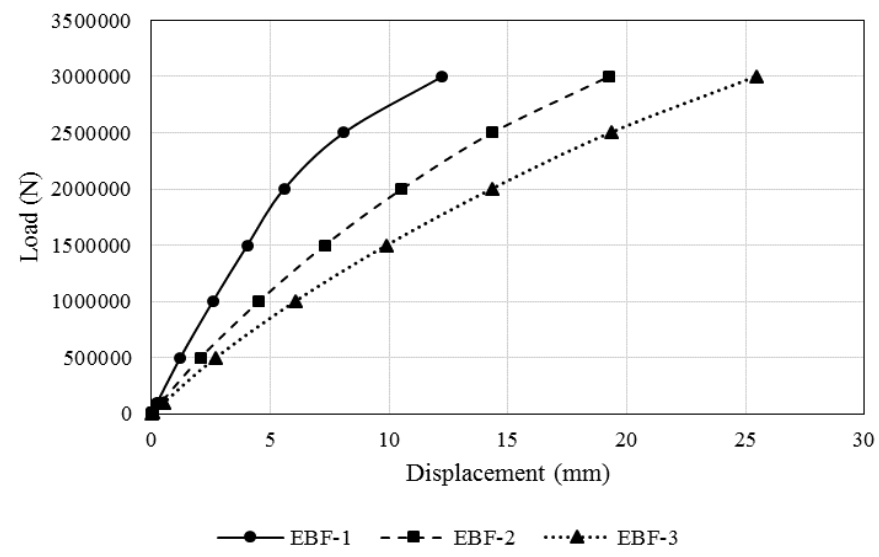

Gambar 10. Perbandingan Perpindahan terhadap Beban

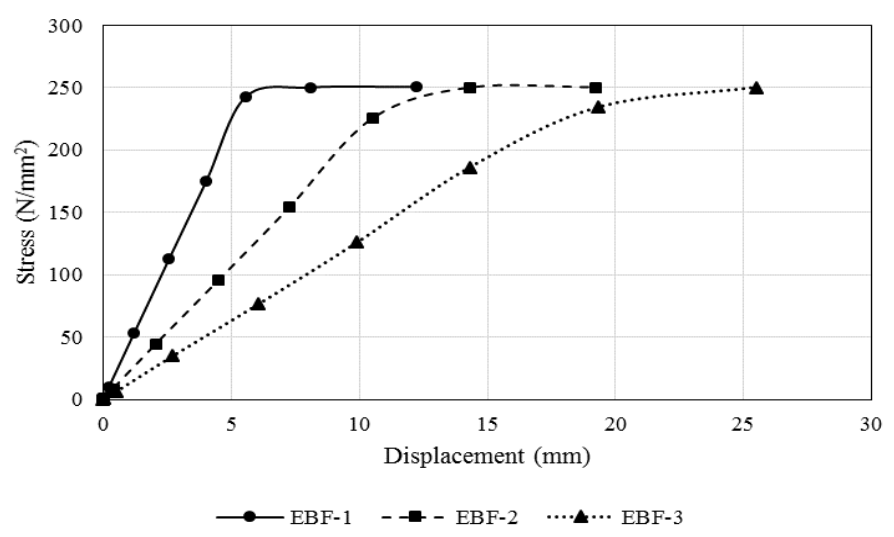

Gambar 11. Perbandingan Perpindahan terhadap Tegangan

perbandingan maka pada portal EBF-2 mengalami peningkatan perpindahan sebesar $36.49 \%$ dan portal EBF3 mengalami peningkatan sebesar $52.02 \%$. Atau dapat dikatakan bahwa perpindahan akhir pada portal EBF-3 mencapai dua kali lipat dari portal EBF-1.

Untuk perbandingan perpindahan terhadap tegangan di setiap portal EBF yang diberikan pada Gambar 11 dapat disimpulkan bahwa link pada portal EBF-1 telah mencapai kondisi leleh ketika perpindahan yang terjadi berkisar $8 \mathrm{~mm}$, link pada portal EBF-2 mencapai kondisi leleh saat perpindahan yang terjadi berkisar $14 \mathrm{~mm}$, sedangkan link pada portal EBF-3 mencapai kondisi leleh saat perpindahan diatas $25 \mathrm{~mm}$. Hal ini menjelaskan bahwa tegangan leleh lebih dahulu tercapai pada portal dengan link pendek sehingga mekanisme keruntuhan pada link dapat terpenuhi dengan baik.

\section{KESIMPULAN}

Penelitian ini memaparkan suatu hasil studi yang dilakukan secara numerik dengan pendekatan finite element terhadap perilaku link pada portal EBF dengan menggunakaan variasi panjang link. Berdasarkan penelitian ini dapat diambil beberapa kesimpulan sebagai berikut: 
1. Portal EBF dengan menggunakan link pendek memberikan respon yang lebih baik dibandingkan dengan menggunakan link menengah ataupun link panjang. Hal ini dikarenakan ketika pembebanan diberikan, link pendek telah menunjukkan mekanisme keruntuhan yang disyaratkan dalam EBF dan distribusi tegangan yang lebih merata pada bidang web.

2. Dengan besaran pembeban yang sama, portal EBF dengan link pendek memiliki kekakuan dan kekuatan yang lebih baik dibanding link menengah dan link panjang yang terlihat dari perpindahan yang dihasilkan pada portal EBF dengan link pendek lebih kecil dibanding model link lainnya.

3. Semakin panjang link, maka mekanisme keruntuhan pada link semakin sulit tercapai karena link berperilaku menjadi seperti balok sehingga dalam penggunaan link panjang harus lebih diperhatikan dalam perencanaan.

\section{DAFTAR PUSTAKA}

[1] Daneshmand, Ardeshir, dan Behrokh H. Hashemi. (2011), "Performance of Intermediate and Long Links in Eccentrically Braced Frames". Journal of Constructional Steel Research, 70 (11) : 167-176.

[2] Engelhardt, Michael D. (2007), "Design of SeismicResistant Steel Building Structrues". AISC Module for Teaching the Principles of Seismic-Resistant Design of Steel Building Structures, American Institute of Steel Construction, Chicago, Illinois.
[3] Ricles, James M., dan Egor P. Popov. (1994), "Inelastic Link Element for EBF Seismic Analysis". Journal of Structural Engineering, 120 (2): 441-463.

[4] Popov. Egor P., Kazuhiko Kasai, dan Michael D. Engelhardt. 1987. "Advances in Design of Eccentrically Braced Frames". Buletin of the New Zealand National Society for Earthquake Engineering, Vol. 20, No. 1, Maret.

[5] Richards, Paul W., dan Chia-Ming Uang. (2005), "Effect of Flange Width-Thickness Ratio on Eccentrically Braced Frames Link Cyclic Rotation Capacity". Journal of Structural Engineering, 131 (10): 1546-1552.

[6] Bruneau, Michel, Chia-Ming Uang, dan Rafael Sabbelli. (2011), "Ductile Design of Steel Structures - Second Edition". McGraw-Hill Companies, Inc., United States of America.

[7] Musmar, M.A. 2012. "Effect of Link on Eccentrically Braced Frames". Journal of Engineering Sciences, Assiut Universiy. Vol 40, 1 (1): 35-43.

[8] Hashemi, Seyed H. (2011), "Ductility and Ultimate Strength of Eccentric Braced Frame". Proceeding of International Conference on Advanced Materials Engineering, Kairo, Mesir, 1-3 Oktober.

[9] Berman, Jeffrey W., Taichiro Okazaki, dan Heidrun O. Hauksdottir. (2010), "Reduced Link Sections for Improving the Ductility of Eccentrically Braced Frame Link-to-Column Connections". Journal of Structural Engineering, 136 (5) : 543-553.

[10] ANSI/AISC, 341-10. (2010), "Seismic Provisions for Structural Steel Buildings". American Institute of Steel Construction, Chicago, Illinois. 